\title{
HERRENS RØST, SOM ALDRIG BRISTER
}

Af Anders Malling.

Professor V. Ammundsen sagde til sine studenter: 》Man skal være meget forsigtig med at sige, at denne eller hin tone ikke findes $\mathrm{i}$ Grundtvigs salmer. Ser man nøjere til, er det der altsammen.« En af grundene til denne alsidighed er, at Grundtvig ikke blot sang ud af sig selv, men bearbejdede fremmed stof. Han kunde vælge dette stof, fordi han følte sig dybt beslægtet med det og vilde give det en passende form eller anvendelse, f. eks. »Den signede dag«; men han kunde ogsaa vælge et stof, som var ham fremmed, maaske endda fjendtligt, blot fordi han blev grebet af visse poetiske billeder eller udtryk, en tanke eller en stemning, og i saa fald maatte han ligefrem bekæmpe det stof, som han bearbejdede. Det gik ofte saadan, naar han var paa mystikkens eller pietismens grund. Resultatet af en saadan omsmeltning og indblanding af grundtvigske ingredienser i malmen kunde blive en fuldstændig grundtvigsk sejr, saa salmen føltes ganske ny, helstøbt og original, f. eks. »Hil dig, Frelser og forsoner«; men det kunde ogsaa blive ganske ødelæggende for salmen, f. eks. »Her vil ties«. Endelig kunde det i et ganske sjældent tilfælde gaa saadan, at der fremgik et kunstværk af arbejdet, skønt Grundtvig med hele sin nyskabervilje og med store poetiske tilskud ikke havde kunnet besejre det stof, han havde bekæmpet. Saaledes gik det med salmen »Herrens røst, som aldrig brister«, som i flere henseender er enestaaende i Grundtvigs produktion. De fleste, som drikker af denne salmes vin, mærker ikke, at den er en blanding, hvori det nye og det gamle ikke vil forliges. De skænker vinen i glasset og ser, at farven er skøn; de fører glasset til munden og mærker, at smagen er bitter og sød som i visse ædle vine. Virkningen er døvende og svalende, henførende og frigørende for fantasien. Dejlig vin, siger man og sætter glasset noget fast i bordet ved det sidste vers! - Vi vil prøve at se paa de forskellige druesafter, der er blandet i dette tilsyneladende grundtvigske bæger.

1. O! der alles hätt' verlohren, auch sich selbst: der allezeit nur das eins hätt' auserkohren, so hertz, geist und seel erfreut. 
2. O! der alles hätt' vergessen, der nichts wüst' als GOtt allein, dessen güte unermessen macht das hertz' still, ruhig, rein.

3. O! wer doch erst wär gekommen durch die liebe recht zu GOtt, dadurch wär' er gantz entnommen allen kummer, angst und noht.

4. O! der alles könnte lassen, dass er frey vom eiteln all wandern möcht' die friedens-strassen durch dies thränen-jammerthal.

5. O! wär' unser hertz entnommen dem, was lockt durch eiteln glantz, und hält ob zu GOtt zu kommen in dem alle güt' ist gantz.

6. O! dass GOtt wir möchten finden in uns durch der liebe licht und uns ewig ihm verbinden, ausser ihm ist eitel nicht.

7. O! wär' unser aug' der seelen stetig nur auf GOtt gewendt, so hätt' auch das sorglich' quälen im gewissen gantz ein end'.

8. O! du abgrund aller güte! zeuch durchs creutz in dich hinein geist, seel, hertz, sinn und gemühte, ewig mit dir eins zu seyn.

Ukendt tysk forfatter, o. 1680.

Her efter Schraders »Vollständiges GesangBuch «, Tondern 1731, nr. 836.

Det er kun logisk, at forfatteren til denne salme er ukendt. Den hører hjemme indenfor den tyske mystik, hvor det ikke kommer an paa navn eller personlighed, men tværtimod paa personlighedens restløse opgaaen i guddommen. Man har tidligere gattet paa, at den var digtet af Gottfried Arnold, ikke just fordi den har umiskendelig lighed med hans øvrige salmer, men fordi den fandtes $i$ hans skrift »Neuer Kern wahrer Geistesgebete, aus lauter Alten genommen etc.《, Leipzig 1703, hvori der er et tillæg »Ein neuer Kern recht geistlicher lieblicher Lieder«, som indeholder 217 salmer, hvoriblandt den foranstaaende, der her har faaet overskriften: »Alles in Einem«. I for- 
ordet siger Arnold, at næsten alle disse salmer er nye. Hvilke han saa selv havde digtet, kunde ikke med sikkerhed fastslaas, men man har plejet at overlade ham dem, som man ikke kunde paavise nogen anden forfatter til.

Imidlertid har I. H. Höck i et hamborgsk menighedsblad fra 1912 paavist, at salmens ældste findested er »Helle leuchtender Herzensspiegel .... alles nach der tiefen Grund- und Kraftlehre des hocherleuchteten J. Tauleri verfasset und eingerichtet«, Frankfurt und Leipzig 1680. Man maa derfor opgive tanken om, at Arnold kan være salmens forfatter; han var paa det tidspunkt kun 14 aar gammel. En forfatter, hvis navn vi nu ikke kender, har bygget den over et sted hos Johann Tauler, hvis skrifter stadig gav motiver til salmedigtning. Den har i den nævnte bog overskriften: „Herzinniger Schlussseufzer, mit Gott vereinigt zu werden $\ll$.

Fischer skriver om den (Kirchenlieder-Lexicon II, Gotha 1879, s. 138), at den er fuld af aand og dybde. Dens værdi er blevet anerkendt af de tyske hymnologer Bunsen i 1833 og I. P. Lange i 1843, men ganske vist ikke uden mangfoldige korrekturer. Saadanne korrekturer har Schrader ogsaa foretaget i den her anførte tekst. Vers 3 lyder oprindelig:

3. O wer doch gar wär ertrunken

In der Gottheit Ungrund-See;

Damit wär er ganz entsunken

Allem Kummer, Angst und Weh.

Dette er mystikkens ægte sprog, men det kunde jo være lidt betænkeligt $\mathrm{i}$ en kirkesalmebog.

Efter en tysk kilde, som $i$ v. 3 ligger originalen nærmere end Schraders tekst, har en ukendt dansk oversætter, maaske en sønderjyde, foretaget følgende oversættelse:

1. O! hvem alting kunde dræbe, med sig Selv, og holde ud,

Eene det at efterstræbe, som giør siælen glad i Gud.

2. O! hvem alting kunde glemme, uden Gud, Hand glædtes ved, i sit hierte at fornemme, een lyksalig Roelighed.

3. O! hvem sig dog lod begrave, I Guds Naades dybe hav, Hand med sig og kunde lave, ald sin Sorg een salig Grav. 
4. O! hvem alting kunde lade, Hand fra Verdens Usselhed frie for Synd og uden skade, kunde komme hiem i fred.

5. $O$ ! at hiertet var betaget, det som Verden haver kier, og til Gud alleene draged, som det største gode er.

6. $\mathrm{O} !$ at $\mathrm{Vi}$ Gud kunde finde, i os med sin Kierlighed, den os skulde da forbinde, avig ham at henge ved.

7. O! Saae stedse Siælens Øye, til sin Gud i Troen hen, Ey Samvittighedens Møye, skulde qvale den igien.

8. O! Du godheds riige Kilde, alle Kræfter ønske sig, du ved Korset giøre vilde, Evig den til Eet med Dig.

Dette er ikke fremragende. Det synes ikke at være nogen stor digter, der har skabt denne oversættelse; men det er maaske nok en teolog; det synes i hvert fald at være en forkynder, der gennem pietismen er blevet kendt med mystikkens sjæle-tekniske sprog.

Saadanne oversættelser gik i anonyme afskrifter fra mand til mand, fra afskriver til afskriver, ikke mindst i Sønderjylland, hvor man de fleste steder ikke havde nogen dansk salmebog. Kongen havde sørget for en officiel dansk salmebog til kongerigerne og en officiel tysk salmebog til hertugdømmerne; men det danske Nordslesvig var dengang som saa ofte før og siden henvist til at hjælpe sig selv. Pontoppidan, som en halv snes aar havde været præst paa Als, først diakon i Nordborg, siden sognepræst i Havnbjerg, før han 1734 blev slotspræst paa Frederiksborg og 1735 hofpræst i København og 1736 fik befaling til at indrette en ny salmebog, har kendt en del af dette haandskrevne materiale og har flittigt gjort brug af det $i$ sin salmebog.

Det har tidligere været almindeligt antaget, at hans amanuensis ved salmearbejdet, Christian Frederik Wadskiær, den senere professor, havde besørget $i$ hvert fald en stor del af de nye oversættelser, som fremkom i Pontoppidans salmebog. Men det maa man vist $i$ fremtiden se bort fra, efter at arkivmaterialet er blevet nærmere 
undersøgt. Disse oversættelser er ogsaa af højst forskellig kvalitet; undertiden er de saa hjælpeløse i deres sprogdragt, at man kommer til at tænke paa det vakte lægfolk i Sønderjylland; undertiden er de elegante og vidner om betydelig litterær dannelse, f. eks. »Mægtigste Kriste«. Den anførte oversættelse kommer ikke i den bedre halvdel.

Men det mærkelige er, at den har været kendt ikke blot blandt jævne folk, men helt op paa kongeslottet, hvor majestæten selv, Christain VI, interesserede sig for dens optagelse. Iblandt de bevarede sparsomme »Forarbejder til Pontoppidans Salmebog« (Rigsark., D. K., Generalkirkeinspektionskollegiet, Diverse Sager. XVIII) findes nemlig et lille læg med tre salmer, hvis fælles omslag bærer følgende udskrift:

\section{Zur Nachricht}

Diese 3. Gesänge stehen schon im Neuen Gesang-Buch. Der mittelste aber ist bey der Censur ausgestrichen, aber einer von denen die der König befohlen aufs neue revidiren.

Also kan dessen übersetzung von neuen nachgesehen werden.

Den første af disse tre salmer er W. C. Deszlers »Wie wohl ist mir, O! Freund der Seelen«, oversat: »Hvor vel er ieg, naar ieg kun hviiler«, som dog ikke blev optaget i salmebogen, skønt den var optaget $\mathrm{i}$ det for censuren forelagte udkast, og censuren ikke synes at have haft noget imod den. Den sidste er J. v. Lodensteins »Heyligster Jesu, Heyligungs Qvelle«, oversat: »Helligste Jesu, helligheds fylde«, som med nogle ændringer genfindes i salmebogen, nr. 494. Men den midterste er just den salme, hvorom det her drejer sig. Om den hedder det altsaa, at den allerede staar i den nye salmebog, hvilket maa betyde i udkastet. Vi kender ikke mere dette udkast, men det staar udtrykkeligt i kongens befaling til Pontoppidan af 3. sept. 1736: »Og naar du med samme Bog er færdig, haver du den til det Theologiske Facultets censur at indlevere, og efter at bemelte Psalmebog af dem er Censureret, haver $\mathrm{Du}$ os den at tilsende, da vi den derefter til Trycken ville lade befordre«. (Sjæll. Tegnelser 1736, 3. sept.).

Derefter er der sket det mærkelige, at kongen har taget sig af visse salmer, som censuren havde strøget, og har givet befaling til, at de paany skulde revideres, naturligvis med det formaal, at de skulde optaget i salmebogen, og censuren skulde have rimelig grund til at ændre sit standpunkt til dem. Det gjorde fakultetet saa grundigt for denne salmes vedkommende, at den blev optaget med det originale v. 3 i Garnisonskirkens tyske salmebog nogle faa aar efter (»NeuEingerichtetes Kirchen- und Haus-Gesang-Buch etc.«, Copenhagen 
1745). Den anførte oversættelse blev altsaa paany »efterseet«, og i den færdige salmebog, nr. 359, fremkom den med følgende ændringer, som dels er sproglige, dels teologiske, og som vel dæmper, men ikke kvæler den oprindelige længselstone efter »unio mystica《;

1,1: O! den alting kunde dræbe. 2,1 og 3,1 og 4,1: O! den. 3,3: Dermed kunde hand vist lave. 4,2-3: Frie for verdens uselhed, Hand foruden synd og skade. 5,3: Og til Gud blev stedse draget.

De tre sidste vers er grundigere ændret:

6. O! at vi Gud kunde finde

Kraftig i os; uden Gud

Intet kand vort saar forbinde,

Eller slukke sorgen ud.

7. Var kun aandens skarpe øye stadig til sin JEsum vendt, Da blev jordisk sorg og møye Ey saa meget følt og kiendt.

8. O! al godheds rige kilde, See! min siel kun ønsker sig, At ved korsets kraft du vilde Drage den ret nær til dig.

Denne oversættelse gik ikke videre til de kommende salmebøger. Allerede Guldberg lod kongen udtale, at »end ikke den ved Vores Hoff brugelige (Psalmebog) har overalt den Rigtighed, Værdighed og Styrke, som Vi ønskede« (Sjæll. Tegnelser 1778, 2. febr.), og dermed var den første oversættelses saga ude.

Men ogsaa Brorson har oversat den tyske salme. Om han har kendt den hidtil omtalte oversættelse er et spørgsmaal. Der er ikke meget $\mathrm{i}$ hans ordvalg, der tyder derpaa, maaske dog »O hvem《. Hans oversættelse fremkom først i Klenodiet 1739, og Pontoppidan har derfor næppe kunnet vide noget om den, før hans salmebog i realiteten var færdig.

1. Hvem der havde dog forlaaret

Alting, ja sig selv forgiæt,

Og det ene kun udkaaret,

Som kand giøre evig mæt!

2. O hvem Gud allene kiendte,

Og det andet havde glemt,

$\mathrm{O}$ hvad kunde Hiertet rente

Blev det i Guds hierte giemt! 
3. O hvem dog ret først var kommen, Indtil Gud i kierlighed! Aldrig blev der da fornommen At man nogen trængsel leed.

4. O hvem alting kunde slippe, At man ræt i frihed stood, Uforandret som en klippe Mod saa megen korses flod.

5. O at verdens glands ey mere Kunde vore hierter naae, Men Gud ene ret begiære, Hvor dog alting er at faae.

6. $O$ at vi Gud maatte finde I os, o hvad var det sødt, Og med ham os ræt forbinde! Uden ham er alting dødt.

7. O var siælens klare øye Stedse til vor Herre vendt! At samvittighedens møye Derved og saa vel var endt.

8. Lær mig siæl og aand at trænge Ind i din foreening ræt, Lær mig det med kors saa længe Til jeg bliver med dig eet.

»Troens Rare Klenodie etc.《, 1739, s. 499.

Med denne tekst er der i Klenodie-udgaven af 1752 foregaaet et par smaa forandringer: 2,3: vente (Arlaud peger paa, at »rente« kunde være en trykfejl, men det kunde ogsaa betyde: hvad vilde det ikke indbringe hjertet, dersom ....). 3,1: først ret. 3,2: Ind til. 7,4: ogsaa. 8,3: ved kors.

Heller ikke denne oversættelse er helt heldig, og det skyldes ikke blot, at ord som »forloret《 (endog stavet »forlaaret«) og »forgiæt《 nu har en anden farve end dengang. Det er baade Brorsons dyd og svaghed som oversætter, at han er saa stærkt bundet af originalen. Han følger den meget samvittighedsfuldt, og det gør ham af og til ufri. Men idet han har lagt Schraders tekst til grund, som det ses af v. 3, har han givet salmen en evangelisk drejning, og han har tilført den umiskendelige poetiske værdier, som Grundtvig ikke var sen til at opdage: »Uden ham er alting dødt«, »sjælens klare øje« osv.

Denne oversættelse havde ingen mulighed for at blive optaget $i$ de officielle salmebøger. Den kom for sent til Pontoppidan, og den 
passede ikke ind i den smag og teologi, som raadede i Guldbergs og Evangelisk-christelig Psalmebog. Den kunde først, som mange andre af Brorsons salmer, faa en chance i Roskilde Konvents salmebog eller dens tillæg, men da havde man Grundtvigs tekst, som ganske overskyggede den.

Salmen »Herrens røst, som aldrig brister《 staar vel for de fleste som en original salme af Grundtvig; den maa ogsaa snarere kaldes en omdigtning end en bearbejdelse. Den fremkom 1851 i Rørdams Mern-Festsalmer nr. 663 og kort efter, men samme aar, i 3. udg. af Grundtvigs egne Festsalmer nr. 694. Denne tekst er optrykt i den nye udgave af Sangværket IV, 229 og er for saa vidt let tilgængelig; den skal dog af praktiske grunde gengives her for at lette sammenligningen.

Mel. Hvem der havde dog forloret.

1. Herrens Røst, som aldrig brister, Lart mig har hvad og jeg troer:

Alt hvad for hans Skyld jeg mister, Faaer igien jeg med hans Ord.

2. Kunde over ham jeg glemme Med mig selv mit eget nu, Hos min Gud jeg da var hjemme Kom som mit Hans Liv ihu.

3. Var kun altid Sjælens Øie Stadig til Vorherre vendt, Da paa Evighedens Høie Pindse-Blus for mig var tændt.

4. Da vidaaben stod Guds Eden For mit Øie og min Fod, I Gudshaven med Gudsfreden Lys jeg drak af Livets Flod!

5. Vilde jeg af intet vide Uden Christi Kiærlighed, Da var mine Kaar saa blide Som min Guds, der alting veed.

6. Fik mit Hjerte ret at finde, Uden ham er alting dødt, $\mathrm{Da}$ var han i Hjertet inde, Med Gudslivet evig sødt!

7. Turde jeg paa Verden træde Med dens Lyster, Guld og Glands, Ind jeg til min Herres Glæde Gik med Brudens Rosenkrands! 
I 6. opl. af Festsalmer 1854 ændrede Grundtvig i 1,4 »med hans Ord« til »paa hans Ord«.

Naar man nu overvejer, hvad der har været hans forlæg for denne gendigtning, kan man vist roligt gaa ud fra, at han ikke har taget særligt hensyn til den tyske originaltekst, om han i det hele taget har undersøgt den. Kun et enkelt sted (3,1-2; originalens v. 7) kunde tyde paa, at han kendte den. Han har i hvert fald kendt den første oversættelse, der er optaget hos Pontoppidan, men den har næppe inspireret ham. Hans forlæg er Brorsons oversættelse, som han har fundet i Klenodiet. Selv om han ikke i Festsalmer som i Sangværket gennem smaa fodnoter gør opmærksom paa sit forlæg, saa har han dog i dette tilfælde røbet det gennem melodiangivelsen, hvor han nævner Brorsons begyndelseslinje. Vi har sandsynligvis kun Brorsons tekst at tage hensyn til. Hvad han har bevaret fra den tyske original, har han i det store og hele med Brorson som mellemled.

Fra den tyske original har han for det første versemaalet, som begge de gamle oversættelser har bibeholdt. Dernæst har han bevaret den konjunktiviske fremstilling, hvormed hele længselstonen er givet. Endvidere har han i v. 2,1-2 gengivet tanker fra originalens v. 2,1-2 og 1,2. Brorsons fine billede i 2,4, 》gemt i Guds hjerte《 omskriver Grundtvig i 2,3 med at »være hjemme hos Gud«. V. 3,1-2 henter han næsten ordret $i$ Brorsons 7,1-2. At han ikke bevarer ordet »klare«, skal senere omtales. V. 5 omskriver Brorsons v. 3. V. 6 omskriver Brorsons v. 6 og bevarer den sidste linje uændret, om end paa en anden plads. Det skønne v. 7 er mere frit formet, men de to første linjer har dog et forbillede i Brorsons v. 5,1-2.

Det er maaske endnu mere lærerigt at lægge mærke til, hvad Grundtvig ikke har bevaret, og hvad han har sat ind i stedet.

Mystikkens maal er selvets og personlighedens udslettelse ved opgaaen i Guddommen, som meget vel kan være upersonligt opfattet. Det omstridte v. 3 i den tyske original er typisk i saa henseende: »at være druknet i Guddommens bundløse hav«. Selv om de øvrige vers er mere kristelige og der ikke mere er tale om »Gottheit«, men »Gott«, og selv om Schrader og efter ham Brorson har ændret det nævnte vers i kristelig retning, saa beholder hele salmen sin smag og duft af mystikken. Paa et hotel i Moseldalen opdagede jeg ved at børste tænder, at vandet $i$ hanerne smagte saa mærkeligt. Da jeg talte med værten derom, fik jeg at vide, at det var ført til hotellets vandbeholder i vintønder. Saadan er det ogsaa med mystikkens salmer; de ord, som har været i vintønden, smager stadig deraf.

Til mystikken hører ogsaa selvforløsningen. Mystikeren naar sit maal gennem en bestemt teknik, ofte gennem askese. En smule kristeligt ændret bliver det til, at jeg gennem en ret forsagelse af ver- 
den kunde blive forenet med Gud. Ikke blot trængslen i verden, men kampen for at gennemføre denne forsagelse, der har noget af selvforløsningen i sig, og samvittighedskvalerne, naar dette ikke lykkes, er det kors, som den tyske original og endnu mere Brorson her taler om. Derfor slutter Brorson i v. 8: »Lær mig .... .

Men da Grundtvig har tænkt over sagen endnu i mange aar, slutter han: »Alt er skænket ..... « Dermed er modsætningen mellem Brorson og Grundtvig egentlig afdækket, og vi er klar over, hvad det er, Grundtvig bekæmper i sit forlæg.

Det har han endnu ikke sagt tydeligt i teksten fra 1851, men han arbejder sig frem i den retning. Han begynder med et helt nyt vers, hvori han indrømmer, at der er noget, som skal læres. Men det har Herrens røst allerede lært ham. Og hvad er saa det? Ikke det Brorsonske »at trænge ind i foreningen med Gud«, men blot det, at han rigeligt vil skænke mig alt, hvad jeg mister ved at følge Kristus efter. Thi Kristus skal følges efter, og det koster forsagelse, og det er vi ikke dygtige til, - og saa falder Grundtvig tilbage paa konjunktiverne: »Kunde, var, vilde, fik, turde«. Men disse konjunktiver er alligevel en smule ændrede. I Brorsons 》O hvem《 ligger skjult et »det er mulig«. I Grundtvigs konjunktiver ligger skjult, at »det er nu engang ikke muligt«. Men hos ham er selve frelsens sag ikke heller afhængig af, at det er muligt. Hans begyndelsesvers har begrænset emnet. Grundforholdet til Gud er stiltiende forudsat, det røber han af udtrykkene »Herrens røst har lært mig«, »paa hans ord«. Det kommer ogsaa tydeligt frem i v. 5, hvor der tales om »Christi Kiærlighed« som noget, vi paa forhaand har, men blot skulde skønne bedre paa. Hos Schrader og Brorson er der derimod tale om vor kærlighed til Gud som et middel til foreningen med Gud. Denne drejning er saare karakteristisk og vidner om, at hos Grundtvig er selve frelsens sag forudsat, og det drejer sig 》blot《 om vanskeligheden ved Kristi efterfølgelse: Jeg vilde have større glæde i mit kristenliv, om jeg bedre kunde følge ham efter.

Saa er der noget forskelligt $i$ selve tonen. Alle versene $i$ den tyske original begynder med et affektfuldt »O!« Den første danske oversættelse har bevaret $\gg 0 ! \ll$ alle otte steder. Pontoppidan sletter det ene $i$ v. 7. Brorson giver afkald paa det to steder, v. 1 og 8. Dette er allerede karakteristisk. Men Grundtvig har ikke et eneste »O! Han bekæmper den ydre affekt, men i hans mere rolige og objektive fremstilling er der alligevel mere varme end hos Brorson, skønt det dog nu drejer sig om en »mindre« sag.

Grundtvigs fornyelse af salmen bestaar ikke blot i denne begrænsning af emnet og den roligere tone med mere bunden varme. Meget vigtigt er det, at personligheden er understreget saa vel hos Gud som 
hos mennesket. I v. 2,3-4 taler han om at være hjemme hos Gud, og det som en personlighed, der har erindring, bevidsthed. Der ligger heri en begrænsning af hans eget ord sglemme sig selv og sit eget « $\mathrm{i}$ de foregaaende linjer; der ligger et korrektiv til Brorsons »gemt i Guds hjerte《 for slet ikke at tale om at lade sig »begrave i naadens dybe hav«. Paa samme maade understreges i v. 5,4 Guds personlighed ved omtalen af hans alvidenhed som noget særligt ved hans bevidsthed.

Endvidere er det værd at lægge mærke til, at det nye, som Grundtvig indføjer $\mathrm{i}$ de konjunktiviske vers $2,3,5,6$ og 7 , findes $\mathrm{i}$ den sidste halvdel af versene. De to første linjer henter tankerne, betingelserne, hos Brorson, men de kristelige saligheder kan Grundtvig bedre male selv. Brorson taler fint om saligheden hist, Grundtvig taler bedst om saligheden her.

Der er dog en ændring, som er værd at bemærke, $i$ betingelsen $i$ v. 3,1-2. Naar Grundvig ikke bevarer Brorsons »klare«, er det næppe for at komme den tyske original nærmere, men for at faa plads til at indføje ordet »stadig«, som her betyder »fast, ufravendt《. Brorsons »stedse《 har han i forvejen gengivet med »altid«. Derved sparer han at komme ind paa »samvittighedens møje«, selvbebrejdelsen for ustadighed. I stedet sætter han billedet af pinseblusset paa evighedens høje. Han har i sin barndom set pinseblussene paa fjerne høje; det var indledningen til kirkefesten og maaske for barnet det morsomste. $\mathrm{Nu}$ som mand og som digter ved han i sandhed, hvad pinsen er. Derfor mener han, at hvis han altid saa fast paa Vorherre, saa vilde han altid have pinse. Det kan han ikke nøjes med to linjer til at omtale; der maa et helt nyt vers til, som derfor ikke er parallelt med de andre konjunktiviske og ikke begynder med et verbum, men med et »da《, der er en gentagelse af »da《 i 3,3 Dette vers er helt nyt og dog ikke nyt. Det er ikke hentet hos Brorson, men hos Grundtvig selv. Det er en miniatureudgave af salmen »I al sin glans nu straaler solen«. Og mens vi er ved pinsen, gaar vi til v. 6,3-4, hvor Gud er »i hjertet inde«, nemlig i Aandens skikkelse (Johs. 14,17-18) og skænker os kristenlivets sødme (Johs. 15,11).

Severinsen har skrevet om denne salme i »Præsteforeningens Blad《 1928, nr. 33; han er klar over dens indre disharmoni, men mener, at det kommer af, »at Salmen efterhaanden er lagt helt om fra en Mystikers Følelsesverden til selve Frelsens Sag«, og idet han peger paa udtrykket »Evighedens Høje« siger han, at »vi er flyttet over i Spørgsmaalet om evig Salighed«. Jeg synes ikke, at han har ret. De seks første vers af salmen har holdt selve frelsens sag uden- 
for, og de har kun udtalt længsel efter et pinseliv, som burde leves her paa jorden.

Men i v. 7 skrider vi over grænsen. Betingelserne i de to første linjer er som sædvanlig inspireret af Brorson, men slutningen er ogsaa her ny og hentyder til lignelsen om de betroede talenter, Math. 25,21 , og her synes virkelig at være tale om den evige salighed, hvad brudebilledet ogsaa antyder, Aab. 18,7-8. Dermed har den gamle salmes konjunktiver lokket Grundtvig til at sige noget, som han i grunden ikke vilde sige, og som heller ikke Brorson har sagt, nemlig at den evige salighed kunde vindes alene ved at forsage verden. Ganske vist ligger der i Grundtvigs »Turde«, at det tør vi ikke, men maa følgen saa ikke blive, at vi slet ikke kan faa den evige salighed?

Det tyggede Grundtvig paa i 13 aar. Sa slettede han dette i formel henseende prægtige vers. Det er faktisk fuldt af »Guld og Glans«. Men det maatte altsaa forsages for den kristelige sandheds skyld. Han digtede $i$ stedet et andet slutningsvers, som først fremkom i 8. udg. af Festsalmer:

\section{Dog, i Jesus-Christus-Navnet \\ Alt er skænket den, som troer, Deri Hjertet Bod for Savnet Finder med Guds Aand og Ord.}

Meningen med lin. 1-2 er, at naaden i Kristus har klaret selve frelsens sag. De sidste linjer taler om sorgen over, at vi ikke kan følge Kristus bedre efter, og længslen efter at kunne gøre det. Men frelsen afhænger ikke af, at vi kan; og ogsaa denne sorg er der bod for i Jesus-navnet. Den er dækket af syndernes forladelse.

Der staar ogsaa en anden melodiangivelse i de senere udgaver af Festsalmer, ikke mere »Hvem der havde dog forloret«, men »Egen Tone«. Og det er sandt. Med dette nye slutningsvers har Grundtvig fundet sin »egen tone«: Alt er skænket!

Hvis Grundtvig nu havde slettet de første halvdele af v. 2, 3, 5 og 6, og erstattet dem med noget andet af hans »egen tone«, saa havde han faktisk sejret over sit forlæg, som han bekæmpede. Men det har han ikke gjort. Han har ment, at salmen nu ikke kunde misforstaas. Han havde med det nye v. 1 begrænset emnet, saa det ikke handlede om selve frelsens sag. Opfyldelsen af betingelserne vilde »blot« give os større salighed her paa jorden. Men naar selv en mand som Severinsen kan forstaa sagen saadan, at det er selve frelsen, det gælder, i v. 2-6, saa maa man vel indrømme, at Grundtvig i kampen mod sit forlæg endnu ikke har sejret over dette. Den gamle salme er som ridderen, der synger om, at han elsker den 
mørke pige. Grundtvigs nye slutningsvers synger om den lyse pige. Men salmen som helhed, som vi nu har den fra Grundtvigs haand, synger:

»Det er, som mit hjerte er delt $\mathbf{i}$ to, det vokser vel sammen med tiden.«

En salme ender normalt med et skjult »altsaa《 eller »derfor《, men denne ender her med et »dog«, som er ganske usædvanligt $i$ salmehistorien. Det vidner om, at striden ikke er bilagt. Grundtvig har i det foregaaende været æstetisk grebet af noget, som han i kristelig henseende maa nære betænkelighed ved. Han er blevet lokket for langt ud. Han har rettet paa det, men det kan maaske stadig misforstaas. Bedst at slaa fast, hvad der er hovedsagen: Dog!

Salmebøgerne har ikke vist den samme selvfornægtelse som Grundtvig i 1864. »Herrens røst, som aldrig brister« blev optaget i første tillæg til Rosk. Konv. sbg. med begge de to slutningsvers, hvoraf det sidste skulde udelukke det første! Man fandt, at det ældste slutningsvers var for skønt at udelade. Saaledes gik den videre til KH 584 og D 528. I Sønderjylland har den gamle salmebog, N 356, optaget Grundtvigs første tekst med kun 7 vers. Hvis man ikke er klar over, at der i kristelig henseende er noget galt deri, saa er det i æstetisk henseende ganske tilfredsstillende. Salmen forekommer ikke disharmonisk, og man ender, som man skal, i Himlen. Men har man opdaget det i kristelig henseende betænkelige, er det rigtigt, som Severinsen siger, at den ender »ligesom resultatløst«: Turde .... men det tør jeg ikke! Om det er derfor, eller fordi det nye slutningsvers ogsaa er kønt, at den nyere sønderjydske salmebog efter genforeningen føjede det til som v. 8, skal jeg lade væres usagt.

Men det rigtigste er, som Grundtvig har gjort. Man burde bringe det offer at fjerne det smukke v. 7. Det efterfølgende »dog《staar ikke i saa skarp modsætning til de første seks vers, men det skriger mod det syvende som for at mane det $\mathrm{i}$ jorden.

Staar man paa »Deutsches Eck«i Koblenz, hvor Rhinen og Mosel flyder sammen, ser man, at det gule vand fra Rhinen og det blaa fra Mosel ikke ret vil blandes, men fortsætter ned ad floden i hver sin side. Ogsaa her i denne salme er to strømme gledet sammen $i$ et fælles leje, og de fleste synes, at det er blevet en prægtig flod, men set fra en teologisk synsvinkel er det klart, at strømmen er gul i den ene side, blaa $i$ den anden.

Hvad der hermed er sagt, fornemmes muligvis ikke af den jævne kirkegænger. Han tager salmen som en opfordring til selvfornægtelse og som en trøst, naar denne selvfornægtelse lykkes for daarligt. Dermed sker der ingen skade; det er netop Grundtvigs intention. 